\title{
Constructing A Prototype of Developing Students' 21st Century Skills; Soft Skills, Hard Skills and Competitiveness at a University in Indonesia
}

\author{
Hadiyanto, \\ \{hadiyanto@unja.ac.id\} \\ Universitas Jambi, Jl. Lintas Jambi - Muara Bulian Km. 15, Mendalo Darat, Jambi Luar Kota, Kota, \\ Indonesia
}

\begin{abstract}
This study aims to report the result of a development process of the prototype of developing students' and graduates $21^{\text {st }}$ century skills at a university. Analysis, Design, Development, Evaluation and Revision (ADDIE) Model were used in this development. Four phases were applied in the process of the development; analysis, design, development and evaluation. The constructed model was validated by three approach, expert validation, users' validation, and try-out validation. The result of the development is a validated model of students' SHC Development that has three main phases; Input, Process and Output. Input consists of three components; course content, SHC component, strategy of students' center approach. Process consists of blended course design, Instruction and students' engagement, and evaluation. While output phase consists of soft skills and hard skills achievement, and students' competitiveness level. This study contributes to current issues of students' $21^{\text {st }}$ century skills.
\end{abstract}

Keywords: $21^{\text {st }}$ Skills, core skills, employability, entrepreneurship, professional competencies, lifelong learning.

\section{Introduction}

The Higher Education in Indonesia is facing unprecedented challenges arising from the convergent impacts of Asian Societies Market. As understood by educators and experts, higher education is as an engine of growth for triggering a country to be able to meet with currents need and to get ready for future challenges. The issue is not only related to curriculum changes in HE but more urgently is related to the ability of fresh graduates to compete in Asean job market, meet employer's expectation, adapt and update their competencies beyond then today challenges. The fresh graduates' competencies should be gained during their education at universities level, which is ideally embedded with curriculum and its implementation. Furthermore, the students are demanded to acquire more soft skills rather than hard skills during their learning at Universities. It is expected that students possess individual competitiveness not only at job market but also in their career development in the future. It is understood that hard skills can be acquire and developed through soft skills practices in the classroom [12], [13]. To response the new policy, most of universities in Indonesia state that soft skills, hard skills and competitiveness as outcome of graduate quality standard of Universities [14]. However, there is no yet clear guidance how the quality standard of graduate achieved and how to embed soft skills and hard skills into teaching and learning process. 
To meet the issues above, specifically at a University, model of students' SHC Development, measurement of Students SHC and manual book of implementation have to be developed. The current study is funded by RISPRO LPDP-Menkeu Indonesia. It developed a model of developing students' SHC. It will be implemented in blended learning activities at a university. The model was developed to be applicable for all fields of study and subjects of teaching. This article aims to define, describe and discuss the process and outcomes of development model of developing students' and graduate soft skills, hard skills and competitiveness (SHC) at a university.

\section{The $21^{\text {st }}$ Century Skills: Soft Skills, Hard Skills and Competitiveness}

The terms used among universities to reveal $21^{\text {st }}$ century skills needed by graduates Universities today are soft skills, professional skills, interpersonal and personal skills, generic skills, key skills, adaptive skills, and this study is using the terms Soft Skills, Hard Skills and Competitiveness or abbreviated by SHC. Thought the different terms used by researchers and academician to express the quality output of graduate, however there is an agreement view that teaching and learning at University are about verifying the students with knowledge and skills which carried out been how to come out with the outcome of university that produces employability, good citizenship and lifelong learners [8], [10] and [20].

The term of $21^{\text {st }}$ Century Skills consist of soft skills, hard skills and competitiveness (SHC). It is defined as a blended ability that possessed by someone in an effort of obtaining his/her objective. At university Level skills developed during teaching and learning process at university in order to provide students with three competencies; Soft Skills and Hard Skills, and competitiveness as outcome of soft kills and hard skills.

Soft skills is defined as practical activities applied to generate and developed hard skills in the students' learning context and graduates' working context. This definition based on analysis and synthesis from related articles as stated in [6], [14] and [23], soft skills include communication skills, IT Skills, numeracy skills, learning skills, problem solving skills and working with others.

Hard skills relate to major and minor knowledge skills. Specifically, in this study, it is defined the ability of person using and generating his/her major specific knowledge skills in real context of learning and working, and it is blended with soft skills. With this competetiveness will be practically embedded in the practice of soft skills and hard skills [14], [16], [24] and [25].

Competitiveness refers to the eagerness and the effort of a person to apply, maintain, and improve and promote his/her soft skills and hard skills in his/work, task and learning consistently. Competitiveness categorized into three capacities; lifelong learning, entrepreneurship and employability. The level of competitiveness level was assumed to be affected by the level of his/her soft skills and hard skills [4], [23], [26], [27]. and [33].

\section{Method to Model Construction and Validation}

Research and development design were applied in this research. The phases and steps of development in this research were adapted from ADDIE model by [17], [18] and [19]. Main phases of the development applied were Analysis, Designing, Developing Evaluation and 
revision. Quantitative and Qualitative method were applied to obtain data and analysis in every phase. The instruments for data collection were literature, questionnaire, interview protocol, SHC assessment rubric, FGD Protocol and document. Three groups of participants were involved; they were stakeholders, lecturers and students.

The first phase of development was analysis of previous researchers' research and publication, HE curriculum, Vision and Mission and strategic plan of a university, survey on students' needs, current literature review, stakeholders' system recruitment and interview. The second phase was designing that included categorizing and defining components of SHC, designing phases and features of students' SHC development in subject learning process and learning strategy for developing students' SHC. The third phase was developing model of students' SHC Development (input, Process, and Output), expert validation, users' validation and try-out validation. The last part of development is evaluation and revision. Due to the aim of the article is to report the construction and validation of the model, the evaluation and revision phase could be covered in this article.

\section{Result of Literature Analysis}

One of step that had been done in students' SHC development model was analysis of literature. It include the content analysis on KKNI-Indonesian qualification framework curriculum, vision and mission and strategic plan of a university, stakeholder interview, FGD and document of system recruitment. Amongst the resources used are such as [1], [2], [3], [4]. [5], [6], [7], [8]. [11], [15], and [20]. Analysis was also conducted to employee system recruitment of $10 \mathrm{Ltds}$ they are PT. Telkom Indonesia, PT. Toyota Corp, PT. Unilever Oleochemical Indonesia, PT. Petrocina Indonesia, PT. SHELL, PT. Pertamina, PT. NESTLE, PT. Rajawali Indonesia. The overall number of resources and references used in developing the model is shown in Table 2.

Table 2. Number of references of defining Soft Skills, Hard Skills, hard skills and its' components.

\begin{tabular}{|c|c|c|c|c|c|c|c|c|c|c|}
\hline \multirow[t]{2}{*}{ Constructs of SHC } & \multicolumn{2}{|c|}{$\begin{array}{l}\text { Literature } \\
\text { studies }\end{array}$} & \multicolumn{2}{|c|}{$\begin{array}{l}\text { System } \\
\text { Recruitment } \\
\text { Document }\end{array}$} & \multicolumn{2}{|c|}{$\begin{array}{l}\text { Interview } \\
\text { Stake } \\
\text { holders }\end{array}$} & \multicolumn{2}{|c|}{$\begin{array}{c}\text { FGD } \\
\text { Lecturers }\end{array}$} & $\begin{array}{l}\text { TOTAL } \\
\text { Resources }\end{array}$ & $\begin{array}{c}\text { TOTAL } \\
\text { References' }\end{array}$ \\
\hline & $\begin{array}{c}\text { Res. } \\
\mathbf{1 1}\end{array}$ & $\begin{array}{c}\text { Ref. } \\
\mathbf{2 9}\end{array}$ & $\begin{array}{c}\text { Res. } \\
\mathbf{1 0}\end{array}$ & $\begin{array}{c}\text { Ref. } \\
\mathbf{1 0}\end{array}$ & $\begin{array}{c}\text { Res. } \\
\mathbf{6}\end{array}$ & $\begin{array}{c}\text { Ref. } \\
8\end{array}$ & $\begin{array}{c}\text { Res. } \\
\mathbf{4}\end{array}$ & $\begin{array}{c}\text { Ref. } \\
\mathbf{1 2}\end{array}$ & $\begin{array}{c}\text { Res. } \\
\mathbf{3 1}\end{array}$ & $\begin{array}{c}\text { Ref. } \\
\mathbf{5 9}\end{array}$ \\
\hline Communication & 11 & 39 & 10 & 10 & 4 & 10 & 4 & 14 & 29 & 73 \\
\hline IT & 8 & 28 & 8 & 10 & 5 & 9 & 4 & 16 & 25 & 63 \\
\hline Numeracy & 5 & 17 & 7 & 8 & 2 & 3 & 4 & 10 & 18 & 38 \\
\hline Learning & 7 & 14 & 7 & 9 & 2 & 4 & 4 & 11 & 20 & 38 \\
\hline Prob. Solving & 9 & 18 & 10 & 10 & 4 & 10 & 4 & 15 & 27 & 53 \\
\hline WWO & 9 & 15 & 10 & 10 & 6 & 11 & 4 & 9 & 29 & 45 \\
\hline Hard Skills & 7 & 18 & 9 & 10 & 3 & 5 & 4 & 11 & 23 & 44 \\
\hline Competitiveness & 11 & 25 & 7 & 8 & 3 & 6 & 4 & 12 & 25 & 51 \\
\hline Entrepreneurship & 9 & 21 & 8 & 7 & 4 & 8 & 4 & 14 & 25 & 50 \\
\hline Lifelong learning & 11 & 16 & 5 & 6 & 5 & 7 & 4 & 10 & 25 & 39 \\
\hline Employability & 15 & 47 & 10 & 9 & 5 & 6 & 4 & 16 & 34 & 78 \\
\hline GRAND TOTAL OF & 113 & 277 & 101 & 107 & 49 & 87 & 4 & 150 & 267 & 631 \\
\hline
\end{tabular}

\section{SHC}




\section{Result of Constructing Students SHC Development Model}

All phases of R \& D as described in part 2 in this article had been conducted and resulted a model of Students $21^{\text {st }}$ Century Skills development those are consists of soft skills, hard skills and competitiveness (see figure 1). The students' SHC Development model is integrated with curriculum, syllabus and lesson plan. Students SHC development occur in blended learning activities in every subject of a program. These theories based on literature studies as discussed above. The phases of students' SHC development are divided into three phases they are input, process and output.

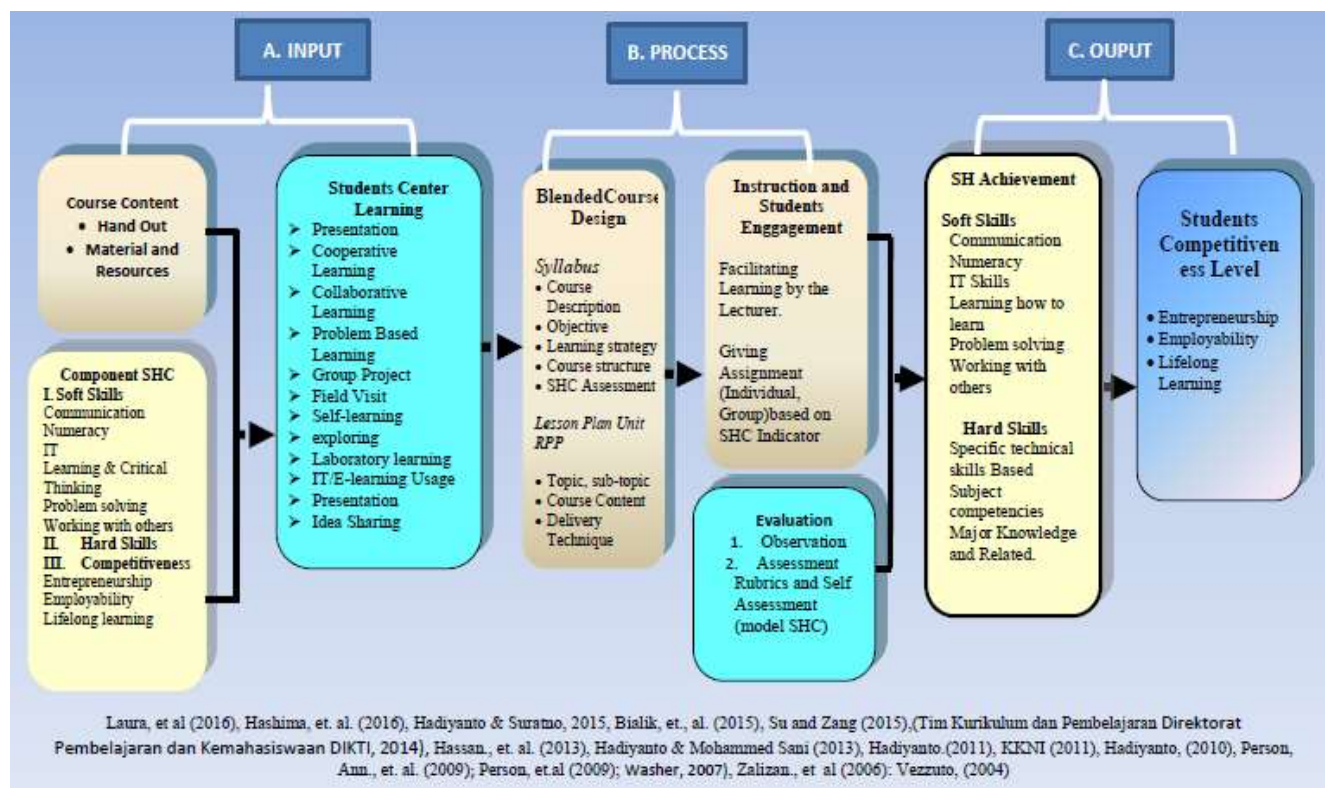

Fig. 2. Model of Students' SHC Development at University.

\section{Result of Try-out Implementation}

Try-out was conducted to $6^{\text {th }}$ semester students at English Department Class for research seminar and proposal course. The try-out was conducted in four meetings. Qualitative and checklist observation were taken by two lecturers. Checklist observation was referring to the SHC rubric assessments indicators [14]. The most frequent indicators that perform by the students in four meetings in the try-out classroom are shown in Table 4 . The result implies that the model would be more optimized if it is applied in full 16 meetings of courses along semester.

Table 4. Observation Findings of students $21^{\text {st }}$ Century skills in try-out classroom.

\begin{tabular}{|l|l|}
\hline \multicolumn{1}{|c|}{ Soft Skills } & \multicolumn{1}{c|}{ Indicators practiced by the students } \\
\hline Communication & $\begin{array}{l}\bullet \text { Communicating or presenting ideas. } \\
\bullet \text { Responding with a clear and straight forward }\end{array}$ \\
\hline IT & $\bullet$ Searching for and select the information through online resources. \\
\hline
\end{tabular}




\begin{tabular}{|l|l|}
\hline & $\begin{array}{l}\text { - Presenting the assignment using power point, graph, chart, image, } \\
\text { number. }\end{array}$ \\
\hline Numeracy & $\begin{array}{l}\text { - Using effective and efficient way to present the materials, information } \\
\text { and findings }\end{array}$ \\
\hline Learning & $\begin{array}{l}\text { - Putting together ideas from different perspectives during discussion. } \\
\text { Identifying problems, using different methods and sources to solve } \\
\text { problems. }\end{array}$ \\
\hline Problem solving & $\begin{array}{l}\text { - Working together and have a serious conversation with the team } \\
\text { - Contributing as team members or team leaders in completing tasks. }\end{array}$ \\
\hline Team work & $\begin{array}{l}\text { - Answering questions and gives specific and practical explanations in } \\
\text { the topics discussed. }\end{array}$ \\
\hline \multicolumn{1}{|c|}{ Competitiveness } & \multicolumn{1}{|c|}{ Indicators showed by some of students } \\
\hline Entrepreneurship & - Promoting his ideas strengths and benefits \\
\hline Lifelong learning & • Showing willingness to learn continuously. \\
\hline Employability & • Completing the tasks assigned and responsible for what he does \\
\hline
\end{tabular}

\section{Discussion}

The purpose of this study was to develop model of students' SHC development through teaching and learning process at a university. This purpose was taken based on initial analysis on Indonesian HE curriculum, current trend of HE curriculum, Vison and Mission of a university, graduates today and future challenges and to meet the global stakeholders' expectation on graduates' quality. The findings of the study is not only implicated to the use of students' SHC development in the teaching and learning process at a university, but it can also implicate to other Universities curriculum changes due to this development has developed on national and global issues of current curriculum changes. Basically, the theoretical analyses had been done since 2007 through the Ph.D thesis, and through this research project the model was reconstructed, adapted, and updated based on current local, Asian and global issues toward the quality of University graduates.

The model is picture out in three phases input, process and output, that is easy for the user to comprehend this model conceptually and practically. Components in each phase had been developed and described concisely and clearly, and supposed to be a friendly reader as well. The teacher then interpreted into their own context of learning. Input is the phase where the teachers selecting resources of learning and defining soft skills and hard skills based on his and her course content. Reading and selecting learning strategies of students centre approach to be embed in the process phase. In process phase, soft skills and hard skills is blended in course description, objective and evaluation. Learning strategies must be defined and matched with the topics of a course in order to be able to generate students' softs skills practices and acquire hard skills [16] and [33]. Evaluation conducted observation using rubric SHC assessment and students SHC self-report assessment and specific course assessment. Lecturer can modify assessment based on his/her course need. Output phase will analyse and report the level of student SHC. Lecturer is suggested to calculate Students' score based on instrument of assessment as mentioned at the process phase.

The advantage of using this model is the course contents are delivered by learning strategies based on students' centre approach that allow the students to practice and develop their soft skills to acquire hard skills [13]. The teachers' role in the classroom is outlining the material, guiding, facilitating the students to generate their basic knowledge toward the topics of a course. In this model, the students' soft skills and hard skills development were observed by using rubrics assessment and student's self-evaluation questionnaire. Both instruments 
consist of indicators that had been developed in different task of this model development [7] and [14]. Both the instrument of students SHC measurement should be used one packet in evaluation students SHC Development through the teaching and learning process. Moreover, it is suggested to combine for measuring students course academic achievement by using both instruments, the score is can be converted into standard score 1 to 100 of University. Though the model was design to be practiced embedded with course content through the teaching and learning process, however the model also applicable to be used for extra curricula program to develop participants' as professional skills training, it depends on the user to adapt based on their need.

\section{Conclusion}

This article presented the process of development of Students' SHC Development Model through the teaching and learning activities at Jambi University. Four phases had been applied and each phases had three steps. The phases are analysis, designing, developing and Evaluation and revision. Though the phases of development is refer to Design, Development, Evaluation and revision (ADDIE) by [17], [18] and [19], steps of development process were adjusted based on need and challenges in order that the model accepted by users (teachers) and policy maker at University. The result of development come out with a model of students' SHC Development in teaching and learning which is break down into of three main parts, input, process and Output. Input is consists of course content, components of SHC, and Students' center learning. Process is consisting of blended course design, instructional and students' engagement, and evaluation for measuring SHC. Output had two sub-parts soft skills and hard skills achievement. Soft skills are output analysis of SHC assessment rubric, and Students SHC self-assessment. The last component of Output was students' competitiveness level. Based on theoretical analysis, it assumes that students' level of soft skills and hard skills level impact on the students competiveness level; entrepreneurship, employability and lifelong learning. In the whole development process, this study can serve as a model of validation research as well as an application and adaption of research and development theory.

\section{References}

[1] Laura H. Lippman, Renee Ryberg, Rachel Carney, Kristin A. Moore Child Trend. Workforce Connections:Key "Soft Skills" That Foster Youth Workforce Success: Toward A Consensus Across Fields. (2015), accessed 03 July 2016; available at https://www.usaid.gov/sites/default/files/documents/1865/KeySoftSkills.pdf.

[2] Hadiyanto and Suratno. 2015. The Practices of Students' Generic Skills among Economics Students at National University of Indonesia. Higher Education Studies, Vol.5.No.2:2015. Canadian Center of Science and Education. Retrived from: http://www.ccsenet.org/journal/index.php/hes/article/view/45364.

[3] Bialik.M., Bogan. M., Fadel. C., Horyathova. M. 2015. Character Education for the $21^{\text {st }}$ Century: What Should Students Learn? Center For Curriculum Redesign. Boston, Massachusetts. Retrieved from: http://curriculumredesign.org/wpcontent/uploads/CCR CharacterEducation_FINAL_27Feb2015.pdf.

[4] ILO. (2014). Survey of ASEAN employers on skills and competitiveness. Emerging Markets Consulting. Retrieved from http://www.ilo.org/wcmsp5/groups/public/---asia/--ro-bangkok/---sro-bangkok/documents/publication/wcms_249982.pdf. 
[5] Hassan. A., Maharoff. M., Abiddin. Z.,N. 2013. The readiness of Lecturers in Embedding Soft Skills in the Bachelor's Degree Program in Malaysian Institutes of Teacher Education. Journal of Education and Training Studies Vol. 2, No. 3; July 2014. Red fame Publishing. Retrived from: http://jets.redfame.com.

[6] Hadiyanto \& Sani. M. 2013. Students' generic skills at the National University of Malaysia and the National University of Indonesia. Procedia - Social and Behavioral Sciences 83 (2013) 71 - 82. Retrived from: www.sciencedirect.com.

[7] Person, Ann, E. Moiduddin, M. Hague-Angus, M. and Malone, L.M. 2009. "Survey of Outcomes Measurement in Research on Character Education Programs (NCEE 2009006)," Washington, DC: National Center for Education Evaluation and Regional Assistance, Institute of Education Sciences, U.S. Department of Education. This report is available on http://ies.ed.gov/ncee/pdf/2009006.pdf

[8] Zalizan Mohd. Jelas, Norzaini Azman, Manisah Mohd. Ali, Norazah Mohd. Nordin, Ab. Halim Tamuri. 2006. "Developing Kompetensi inti at Graduates: A Study of Effective Higher Education Practices in Malaysian Universities" in Summary Report. Bangi: Faculty of Education, Universiti Kebangsaan Malaysia.

[9] Rajadurai, J., Sapuan, N.M., Daud, S. Salina Daud., Abidin, N (2018). The Marketability of Technical Graduates from Higher Educational Institutions (HEIs) Offering Technical and Vocational Education and Training (TVET): A Case from Malaysia. Asia-Pacific Edu Res. 27: 137. 535-543. https://doi.org/10.1007/s40299$\underline{018-0372-7}$

[10] Partnership for 21st Century Skills. (2008). 21st Century Skills, Education \& Competitiveness.A Resources and Policy Guide. Retrieved 21, February, 2017, from http://www.p21.org/storage/documents/21st_century_skills_ education_and_competitiveness_guide.pdf

[11] Ristekdikti (2015). Standar Nasional Pendidikan Tinggi (SN Dikti). Direktorat Penjaminan Mutu http://bpm.umsida.ac.id/wp-content/uploads/2017/08/3.-StandarNasional-Pendidikan-Tinggi-SN-Dikti.pdf

[12] Biggs J \& Tang C., 2011., Teaching for Quality Learning at University., 4th Edition, Society for Research into Higher Education \& Open University Press.

[13] Herod, L. (2002). Adult learning: From theory to practice. Retrieved 24, February, 2017, from en.copian.ca/library/learning/adult_learning/adult_learning.pdf

[14] Hadiyanto, Noferdiman, Moehamin, Yuliusman.2017a. ASSESSING Students And Graduates Soft Skills, Hard Skills And Competitiveness: International Journal of Social Sciences. $\quad 3 \quad$ (2). https://www.grdspublishing.org/index.php/people/article/view/728.

[15] Kemendikbud, 2014. Buku Kurikulum Pendidikan Tinggi..Direktorat Pembelajaran Dan Kemahasiswaan Direktorat Jenderal Pendidikan Tingg http://lpm.walisongo.ac.id/wp-content/uploads/2016/06/Panduan-Kurikulum-Dikti.pdf.

[16] Ahlstrom, A. W., Yohalem, N., David, Ji, P., Hillaker, P., \& David, P. (2014). From Soft Skills to Hard Data: Measuring Youth Program Outcomes. Retrieved 17, February, 2017. Retrieved from http://www.searchinstitute.org/sites/default/files/a/DAP-Ready-by-21-Review.pdf.

[17] Branch, Robert Maribe. (2009). Instructional Design: The ADDIE Approach. USA: Springer.

[18] Richey, R. C., \& Klein, J. D. (2007). Design and development research. Mahwah, NJ: Lawrence Erlbaum Associates, Publishers. 
[19] Dick, W., Carey, L., \& Carey, J. O. (2001).The systematic design of instruction (5th edn). NewYork: Addison-Wesley Educational Publishers.

[20] Hadiyanto. 2010. The Development of Core Competencies at Higher Education: A Suggestion Model for Universities in Indonesia.Educare, 3(1) Bandung 